\title{
PENERAPAN PENDEKATAN PEMBELAJARAN OPEN ENDED DAN PROBLEM POSING DENGAN MEDIA POHON MATEMATIKA UNTUK MENINGKATKAN KEMAMPUAN BERPIKIR KREATIF DAN HASIL BELAJAR
}

\author{
Azin Taufik \\ Program Studi Pendidikan Matematika, Universitas Kuningan \\ azin.taufik@gmail.com
}

\begin{abstract}
Based on interviews and observations which did by researcher before doing research obtained information that creative thinking ability and students learning result of class $X$ A of MAN Malang II Batu City still relatively low, it is because in teaching the teacher only give the procedure a matter without explaining what the procedures used. This research aims to know whether the open ended approach and problem posing with mathematical tree media can improve the creative thinking ability and learning result the trigonometry of students X A Man Malang II Batu City. Based on research which has been done found the following matters: (1) creative thinking ability of students in the cycle I classified as "creative" is the percentage of success is $67.85 \%$ while in the cycle II increased with the percentage of success is $78.57 \%$ classified as "very creative"; (2) completeness of students learning result in the cycle I still was reached 50.00\% with students who completed study are 14 students and who did not complete study are 14 students with class average 63.25, while in the cycle II was reached $89.28 \%$ with students who completed study are 25 students and who did not complete study are 3 students with class average 80.46; (3)management open ended learning approach and problem posing with mathematical tree media in the cycle I was reached $88 \%$ classified as the criteria "very good" and in the cycle II was reached $100 \%$ classified as the criteria "very good" it is shown by the implementation all indicators and descriptors open ended learning approach and problem posing with mathematical tree media are very good; and (4) student's activities in the learning using open ended learning approach and problem posing with mathematical tree media in the cycle I was reached $82.50 \%$ classified as "very good" and more enhanced again in the cycle II up to $100 \%$ classified as the criteria "very good", it is shown with the students who had dared to asking about something which have not understood, the students dared to expressed their opinion in making the questions and answer through mathematical tree media, the students dare to presented the result of their work in front of the class.
\end{abstract}

Keywords: open ended, problem posing, mathematical tree media, creative thinking ability, and learning result.

\section{PENDAHULUAN}

Pengajar matematika dalam mengajarkan matematika di sekolah, kebanyakan hanya mengajarkan prosedur tanpa menjelaskan mengapa prosedur tersebut digunakan. Hal ini mengakibatkan siswa beranggapan bahwa dalam menyelesaikan masalah cukup memilih prosedur penyelesaian yang sesuai dengan masalah yang diberikan. Dalam hal ini fokus pembelajaran tidak pada mengapa prosedur itu yang digunakan untuk menyelesaikan masalah dan pada bagaimana menyelesaikan masalah dengan prosedur tersebut, tetapi prosedur mana yang dipilih untuk menyelesaikan masalah dan pada bagaimana menyelesaikan dengan prosedur tersebut. Dengan penekanan pembelajaran hanya pada prosedur mengakibatkan kreativitas siswa tidak berkembang secara optimal (Subanji, 2007:6). 
Berdasarkan observasi yang dilakukan dengan guru matematika MAN Malang II Kota Batu, bahwa nilai matematika siswa kelas X masih terbilang rendah. Hal ini bisa dilihat dari hasil ulangan pada ujian tengah semester yang rata-ratanya masih dibawah standar SKBM (Standar Ketuntasan Belajar Minimum) sekolah, yaitu 65. Padahal, dalam kelas X yang terbagi 8 kelas, yaitu kelas X A, X $\mathrm{B}, \mathrm{X} \mathrm{C}, \mathrm{X} \mathrm{D}, \mathrm{X} \mathrm{E}, \mathrm{X} \mathrm{F}, \mathrm{X} \mathrm{G}$, dan X H tidak ada perbedaan perlakuan dalam pemberian metode pembelajaran, yaitu masih sama-sama menggunakan metode konvensional. Dalam proses belajar mengajar matematika, guru di MAN Malang II Kota Batu kelas X hanya mengajarkan prosedur penyelesaian suatu soal tanpa menjelaskan mengapa prosedur tersebut digunakan untuk menyelesaikan suatu masalah. Akibatnya, kreativitas dan hasil belajar siswa tidak berkembang secara optimal. Hal ini juga didukung data pada tes awal berpikir kreatif siswa, dari hasil tes awal ini diperoleh persentase keberhasilan 21,43\%, yang berarti kemampuan berpikir kreatif siswa masih tergolong kurang kreatif.

Untuk mengatasi masalah tersebut, maka perlu adanya suatu pendekatan dalam pembelajaran matematika sehingga dapat membantu mengembangkan kemampuan berpikir kreatif dan hasil belajar siswa. Dalam pembelajaran matematika, pengajuan soal menempati posisi yang strategis, pengajuan soal merupakan inti terpenting dalam disiplin matematika dan dalam berpikir matematis.

Pengajuan masalah merupakan tugas kegiatan yang mengarah kepada sikap kritis dan kreatif. Selain problem posing, pembelajaran matematika dengan pendekatan open ended juga bermanfaat dalam meningkatkan cara berpikir siswa. Sejalan dengan pendapat ahli, Suherman dkk (2003:124) menyatakan bahwa pembelajaran dengan pendekatan open ended dapat memberikan keleluasaan kepada siswa untuk berpikir secara aktif dan kreatif dalam menyelesaikan suatu permasalahan.

Pendekatan open ended merupakan pendekatan pembelajaran yang dilakukan dengan menyajikan masalah yang memiliki jawaban tidak tunggal atau cara menyelesaikan tidak tunggal. Karena itu pendekatan open ended dapat dikelompokkan menjadi dua model: (1) masalah dirancang dengan jawaban tidak tunggal dan (2) masalah yang memiliki jawaban tunggal tetapi cara penyelesaiannya tidak tunggal. Ketika masalah dirancang dengan jawaban tidak tunggal, maka proses berpikir siswa akan bebas menentukan bentuk jawabannya, asalkan jawaban tersebut logis dan rasional. Begitu juga untuk masalah yang memiliki jawaban tunggal tetapi cara penyelesaiannya tidak tunggal, maka siswa dapat menyelesaikan dengan berbagai bentuk, yang penting proses penyelesaian tersebut logis dan rasional. Dengan jawaban atau proses tidak tunggal tersebut dapat mendorong siswa untuk berpikir kreatif.

Berdasarkan konteks penelitian yang telah diuraikan di atas, maka fokus penelitian ini adalah "Pendekatan pembelajaran open ended dan problem posing dengan media pohon matematika yang dapat meningkatkan kemampuan berpikir kreatif dan hasil belajar trigonometri siswa X A MAN Malang II Kota Batu.

Dengan berdasar pada fokus penelitian tersebut, maka masalah dalam penelitian ini adalah apakah penerapan pendekatan pembelajaran open ended dan problem posing dengan media pohon matematika dapat meningkatkan kemampuan berpikir kreatif dan hasil belajar trigonometri siswa X A MAN Malang II Kota Batu.

Sesuai fokus dan masalah penelitian di atas, maka tujuan dalam penelitian ini adalah untuk mengetahui apakah pendekatan pembelajaran open ended dan problem posing dengan media pohon matematika dapat meningkatkan kemampuan berpikir kreatif dan hasil belajar trigonometri siswa X A MAN Malang II Kota Batu.

\section{KAJIAN TEORI \\ Pendekatan Pembelajaran}

Pendekatan pembelajaran dapat diartikan sebagai titik tolak atau sudut pandang kita terhadap proses pembelajaran, yang merujuk pada pandangan tentang terjadinya suatu proses yang sifatnya masih sangat umum, di dalamnya mewadahi, menginsiprasi, menguatkan, dan melatari metode pembelajaran dengan cakupan teoretis tertentu (Sudrajat, 2008). Pendekatan yang digunakan dalam penelitian ini adalah pendekatan open ended dan problem posing.

\section{Pendekatan Open Ended}

Pendekatan open ended merupakan pendekatan pembelajaran yang dilakukan dengan menyajikan masalah yang memiliki jawaban tidak tunggal atau cara menyelesaikan tidak tunggal 
(Subanji, 2007:4). Karena itu pendekatan open ended dapat dikelompokkan menjadi dua model: (1) masalah dirancang dengan jawaban tidak tunggal dan (2) masalah yang memiliki jawaban tunggal tetapi cara penyelesaiannya tidak tunggal. Ketika masalah dirancang dengan jawaban tidak tunggal, maka proses berpikir siswa akan bebas menentukan bentuk jawabannya, asalkan jawaban tersebut logis dan rasional. Begitupula untuk masalah yang memiliki jawaban tunggal tetapi cara penyelesaiannya tidak tunggal, maka siswa dapat menyelesaikan dengan berbagai bentuk, yang penting proses penyelesaian tersebut logis dan rasional. Dengan jawaban atau proses tidak tunggal tersebut dapat mendorong siswa untuk berpikir kreatif.

Tujuan dari pendekatan open ended menurut Nohda (dalam Suherman dkk., 2003:124) adalah untuk membantu mengembangkan kegiatan kreatif dan pola pikir matematis siswa melalui problem solving secara simultan. Dengan kata lain kegiatan kreatif dan pola pikir matematis siswa harus dikembangkan semaksimal mungkin sesuai dengan kemampuan setiap siswa. Hal yang harus digaris bawahi adalah perlunya memberi kesempatan siswa untuk berpikir dengan bebas sesuai dengan minat dan kemampuannya.

\section{Pendekatan Problem Posing}

Silver (dalam Subanji, 2007:2) menjelaskan bahwa biasanya problem posing digunakan pada tiga bentuk kegiatan kognitif matematika yaitu:

- Presolution posing, siswa menghasilkan soal-soal awal yang ditimbulkan oleh stimulus.

- Within solution posing, siswa merumuskan soal yang dapat diselesaikan.

- Postsolution posing, siswa memodifikasi kondisi soal yang telah diselesaikan untuk menghasilkan soal-soal baru. adalah:

Beberapa manfaat pengajuan soal menurut English (dalam Subanji, 2007:3) antara lain

- Membantu peserta didik dalam mengembangkan keyakinan dan kesukaran terhadap matematika, sebab ide-ide matematika peserta didik disertakan untuk memahami masalah yang sedang dikerjakan dan dapat meningkatkan kemampuannya dalam pemecahan masalah.

- Merupakan tugas kegiatan yang mengarah pada sikap kritis dan kreatif.

- Mempunyai kemampuan positif dalam memecahkan masalah dan sikap peserta didik terhadap matematika.

- Dapat mempromosikan semangat inkuiri dan membentuk pikiran yang berkembang dan fleksibel.

- Mendorong peserta didik untuk lebih bertanggung jawab dalam belajarnya.

- Mengetahui kesalahan atau miskonsepsi peserta didik.

- Mempertinggi kemampuan memecahkan masalah peserta didik, sebab pengajuan soal memberi penguatan -penguatan dan memperkaya konsep-konsep dasar.

- Menghilangkan kesan "keseraman" dan "kekunoan" dalam belajar matematika.

- Mempersiapkan pola pikir atau kriteria berpikir matematis, berkorelasi positif dengan kemampuan memecahkan masalah.

\section{Rancangan Media Pohon Matematika Berdasarkan Pendekatan Open Ended dan Problem Posing}

Pohon matematika adalah media pembelajaran yang diwujudkan dengan gambar pohon. Pohon terdiri dari batang, ranting, dan daun. Batang merupakan materi utama dalam matematika, ranting berisi jawaban, dan daun berisi masalah-masalah dari jawaban yang terdapat pada ranting atau sebaliknya. Pohon matematika memadukan karakteristik-karakteristik yang terdapat pada pembelajaran open ended dan problem posing. Dalam pohon matematika, siswa diminta untuk mengajukan masalah dari stimulus yang sudah diberikan. Stimulus tersebut bisa berupa soal atau jawaban. Jika stimulusnya berupa jawaban, maka siswa berusaha untuk mengajukan soal-soal yang sesuai dengan jawaban yang sudah diberikan. Hal ini merupakan karakteristik dari pembelajaran problem posing. Soal-soal yang diajukan siswa tidak tunggal sehingga siswa bisa menghasilkan bermacam-macam soal dari suatu jawaban yang diberikan (open ended). Sedangkan apabila stimulusnya berupa soal, maka siswa harus mencari jawaban-jawaban dari soal tersebut. Karakteristik pembelajaran open ended terlihat ketika siswa mencoba untuk berpikir secara aktif dan kreatif dalam 
memecahkan soal-soal yang diberikan. Dari suatu soal dapat dihasilkan bermacam-macam jawaban. Oleh karena itu siswa mendapat kesempatan untuk memperoleh pengetahuan melalui pengalaman menemukan, mengenali, dan memecahakan masalah dengan mengunakan beberapa cara. Dengan demikian cara berpikir siswa dapat terlatih dengan baik dan dapat merangsang kreativitas siswa.

Tabel 1. Rancangan Pohon Matematika

\begin{tabular}{|c|c|c|}
\hline Open Ended & Problem Posing & Pohon Matematika \\
\hline $\begin{array}{l}\text { Karakteristik: } \\
\text { 1. Permasalahn (problem) yang } \\
\text { memiliki metode atau selesaian } \\
\text { yang benar lebih dari satu } \\
\text { 2. Permasalahan (problem) yang } \\
\text { memiliki banyak cara untuk } \\
\text { mendapatkan penyelesaian }\end{array}$ & $\begin{array}{l}\text { Karakteristik: } \\
\text { 1. Menghasilkan soal-soal awal } \\
\text { yang ditimbulkan oleh } \\
\text { stimulus (formal atau } \\
\text { informal). } \\
\text { 2. Merumuskan soal yang } \\
\text { dapat diselesaikan. } \\
\text { 3. Memodifikasi kondisi soal } \\
\text { yang sudah diselesaikan } \\
\text { untuk menghasilkan soal- } \\
\text { soal baru. }\end{array}$ & $\begin{array}{l}\text { Karakteristik: } \\
\text { 1. Stimulus berupa jawaban } \\
\text { atau soal } \\
\text { 2. Jika stimulusnya berupa } \\
\text { jawaban, maka siswa } \\
\text { mengajukan masalah- } \\
\text { masalah (problem posing) } \\
\text { dan masalah-masalah yang } \\
\text { bisa diajukan tidak tunggal } \\
\text { (open ended) } \\
\text { 3. Jika stimulusnya berupa } \\
\text { soal, maka siswa } \\
\text { mengajukan jawaban- } \\
\text { jawaban yang tidak tunggal } \\
\text { (open ended). }\end{array}$ \\
\hline
\end{tabular}

Dalam pembelajaran matematika dengan pohon matematika ini, semakin banyak masalah yang dibuat, maka pohon tersebut semakin memiliki banyak daun, berarti semakin "rindang". Sebaliknya bila daun yang dibuat salah, maka daun tersebut menjadi "benalu" yang mengurangi kesuburan pohon. Kerindangan pohon matematika ini menunjukkan kreativitas siswa (Subanji, 2007:9).

Peraturan dalam pohon matematika adalah sebagai berikut:

- Pohon yang paling baik adalah pohon yang semakin lebat atau pohon yang semakin subur.

- Daun-daun (masalah atau jawaban) yang benar akan menambah nilai siswa yang membuat pohon matematika tersebut.

Apabila masalah atau jawaban yang diajukan salah (daun yang dibuat salah), maka daun tersebut akan menjadi benalu. Artinya, hal ini tersebut akan mengurangi nilai siswa yang mengkontruksi pohon matematika atau tidak menambah nilai bagi siswa.

Sedangkan dalam penelitian ini, peneliti membagi tahapan atau langkah-langkah dalam pembelajaran dengan pendekatan pembelajaran open ended dan problem posing dengan media pohon matematika adalah sebagai berikut.

Tabel 2. Langkah-Langkah Pendekatan Pembelajaran Open Ended dan Problem Posing dengan Media Pohon Matematika

\begin{tabular}{|c|c|c|c|}
\hline Tahapan & Kegiatan & $\begin{array}{c}\text { Langkah-langkah } \\
\end{array}$ & Keterangan \\
\hline Tahap 1 & Penyajian materi & $\begin{array}{l}\text { - Membuka proses belajar mengajar dengan } \\
\text { salam dan mempresensi. } \\
\text { - Memotivasi siswa dengan mengingatkan } \\
\text { pembelajaran sebelumnya. } \\
\text { - Menyampaikan tujuan pembelajaran } \\
\text { - Mengarahkan guru untuk tidak } \\
\text { mendominasi kelas } \\
\text { - Mengarahkan siswa untuk aktif di dalam } \\
\text { proses pembelajaran } \\
\text { - Menyajikan materi }\end{array}$ & Metode Ekspositori \\
\hline Tahapan & Kegiatan & Langkah-langkah & Keterangan \\
\hline & & $\begin{array}{l}\text { Memberikan stimulus kepada siswa } \\
\text { tentang materi yang diajarkan berupa } \\
\text { pertanyaan }\end{array}$ & \\
\hline
\end{tabular}




\begin{tabular}{|c|c|c|c|}
\hline & & $\begin{array}{l}\text { - Meminta siswa untuk membuat soal } \\
\text { sebanyak-banyaknya }\end{array}$ & \\
\hline Tahap 2 & $\begin{array}{l}\text { Tahap merancang } \\
\text { pohon matematika }\end{array}$ & $\begin{array}{l}\text { - Menjelaskan aturan belajar dengan media } \\
\text { pohon matematika } \\
\text { - Memberi kesempatan kepada siswa untuk } \\
\text { bertanya jika belum jelas } \\
\text { - Menyediakan sarana dan prasarana untuk } \\
\text { kegiatan pembelajaran } \\
\text { - Membantu/mendampingi siswa dalam } \\
\text { bekerja } \\
\text { - Mengarahkan siswa untuk menyelesaikan } \\
\text { soal dalam menumbuhkan daun pada } \\
\text { media pohon matematika } \\
\text { - Mengarahkan siswa untuk membuat soal } \\
\text { yang memiliki selesaian yang tidak } \\
\text { tunggal }\end{array}$ & $\begin{array}{l}\text { Open Ended dan } \\
\text { Problem Posing }\end{array}$ \\
\hline Tahap 3 & Tahap evaluasi & $\begin{array}{l}\text { - Menunjuk siswa untuk mempresentasikan } \\
\text { hasil pekerjaanya di depan. } \\
\text { - Membuat kesimpulan bersama dengan } \\
\text { siswa } \\
\text { - Memberikan tugas dan gambaran materi } \\
\text { pada pertemuan berikutnya } \\
\text { - Mengakhiri pembelajaran dengan salam }\end{array}$ & $\begin{array}{l}\text { Diskusi dengan } \\
\text { siswa dilanjutkan } \\
\text { bersama guru }\end{array}$ \\
\hline
\end{tabular}

\section{Berpikir Kreatif}

Menurut Warli (2005:122) berpikir kreatif adalah aktivitas mental yang memperhatikan keaslian dan wawasan (pengetahuan). Johnson (2007:214) menyatakan berpikir kreatif adalah sebuah kebiasaan dari pikiran yang dilatih memperhatikan intuisi, menghidupkan imajinasi, mengungkapkan kemungkinan baru, membuka sudut pandang yang menakjubkan, dan membangkitkan ide-ide yang tidak terduga. Sedangkan kemampuan berpikir kreatif adalah kemampuan seseorang memikirkan dan memberikan gagasan-gagasan baru dan menerapkannya dalam pemecahan masalah. Berpikir kreatif memungkinkan siswa untuk mempelajari masalah secara sistematis, mempertemukan banyak tantangan dengan cara yang terorganisasi, merumuskan pertanyaan-pertanyaan yang inovatif dan merancang penyelesaian yang asli. Dalam penelitian ini berpikir kreatif adalah suatu proses berpikir siswa dalam memberikan gagasan-gagasan baru yang diterapkan dalam pembuatan soal beserta pemecahan masalahnya.

Menurut Guilford (dalam Warli, 2005:123) menyatakan bahwa ada lima sifat yang menjadi indikator berpikir kreatif, yaitu sebagai berikut:

- Kelancaran (fluency), yaitu kemampuan untuk menghasilkan banyak gagasan.

- Keluwesan (flexibility), yaitu kemampuan untuk mengemukakan bermacam-macam pemecahan atau pendekatan terhadap masalah.

- Keaslian (originality), yaitu kemampuan untuk mencetuskan gagasan-gagasan dengan caracara yang asli, tidak klise.

- Penguraian (elaboration), yaitu kemampuan untuk menguraikan sesuatu secara terinci.

- Perumusan kembali (redefinition), yaitu kemampuan untuk meninjau suatu persoalan berdasarkan perspektif yang berbeda dengan apa yang sudah diketahui oleh banyak orang. Johnson (2007:215) menyatakan berpikir kreatif membutuhkan ketekunan, disiplin diri, dan perhatian penuh, meliputi aktivitas mental seperti:

- Mengajukan pertanyaan.

- Mempertimbangkan informasi baru dan ide-ide yang tak lazim dengan pikiran terbuka.

- Membangun keterkaitan, khususnya diantara hal-hal yang berbeda.

- Menghubung-hubungkan berbagai hal dengan bebas.

- Menerapkan imajinasi pada setiap situasi untuk menghasilkan hal baru dan berbeda. 

bawah ini.

Dalam penelitian ini indikator berpikir kreatif yang akan diukur dapat dilihat pada tabel di

Tabel 3. Indikator Berpikir Kreatif

\begin{tabular}{|c|l|cl|}
\hline No & \multicolumn{1}{|c|}{ Aspek yang dinilai } & \multicolumn{1}{c|}{ Deskriptor } \\
\hline 1 & Kelancaran (fluently) & $\checkmark$ & $\begin{array}{l}\text { Siswa dapat mengajukan banyak pertanyaan atau soal } \\
\text { materi trigonometri. }\end{array}$ \\
\hline 2 & Keaslian (Originality) & $\begin{array}{l}\text { Siswa dapat membuat penyelesaian atau jawaban } \\
\text { yang bermacam-macam dari soal trigonometri yang } \\
\text { diajukan. }\end{array}$ \\
\hline 3 & Penguraian (Elaboration) & $\checkmark \begin{array}{l}\text { Siswa dapat membuat soal materi trigonometri, dan } \\
\text { soal yang dibuat merupakan hal yang baru. }\end{array}$ \\
\hline $\begin{array}{l}\text { Siswa dapat membuat soal materi trigonometri } \\
\text { dengan kategori mudah, sedang, dan sukar } \\
\text { berdasarkan pada taksonomi Bloom. }\end{array}$ \\
\hline
\end{tabular}

\section{Hasil Belajar}

Menurut Sudjana (2006:22) hasil belajar adalah kemampuan-kemampuan yang dimiliki siswa setelah ia menerima pengalaman belajarnya. Gagne (dalam Sudjana, 2005:22) membagi lima kategori hasil belajar, yakni: (a) informasi verbal, (b) keterampilan intelektual, (c) strategi kognitif, (d) sikap, dan (e) keterampilan motoris. Dalam sistem pendidikan nasional rumusan tujuan pendidikan, baik tujuan kurikuler maupun tujuan instruksional, menggunakan klasifikasi hasil belajar dari Bloom (dalam Sudjana, 2005:22-23) yang secara garis besar membaginya dalam 3 ranah yaitu:

- Ranah kognitif berkenan dengan hasil belajar intelektual yang terdiri dari enam aspek, yakni pengetahuan atau ingatan, pemahaman, aplikasi, analisis, sintesis dan evaluasi.

- Ranah afektif berkenaan dengan sikap yang terdiri atas lima aspek, yakni penerimaan, jawaban atau reaksi, penilaian, organisasi dan internalisasi.

- Ranah psikomotori berkenaan dengan hasil belajar keterampilan dan kemampuan bertindak, ada enam aspek ranah psikomotorik yakni (a) gerakan refleks, (b) keterampilan gerak dasar, (c) kemampuan perceptual, (d) keharmonisan atau ketepatan, (e) gerakan keterampilan kompleks, dan (f) gerakan akspresif dan interpretative.

Ketiga ranah tesebut menjadi objek penilaian hasil belajar. Diantara ketiga ranah itu, ranah kognitiflah yang paling banyak dinilai oleh guru karena berkaitan dengan kemampuan para siswa dalam menguasai isi bahan pengajaran, oleh karena itu dalam penelitian ini hasil belajar siswa diukur dari ranah kognitif saja dengan soal tes.

\section{METODE PENELITIAN \\ Pendekatan dan Jenis Penelitian}

Penelitian ini berusaha mendeskripsikan pendekatan pembelajaran open ended dan problem posing dengan media pohon matematika untuk meningkatkan kemampuan berpikir kreatif dan hasil belajar trigonometri dengan pendekatan kualitatif..

Ditinjau dari bagaimana penelitian ini dilakukan, maka penelitian ini termasuk penelitian classroom action research atau yang lebih dikenal penelitian tindakan kelas (PTK), yaitu suatu bentuk penelaahan penelitian yang bersifat reflektif dengan melakukan tindakan-tindakan tertentu agar dapat memperbaiki dan meningkatkan praktik-praktik pembelajaran di kelas secara lebih profesional (Basrowi dan Suwandi, 2008:28).

\section{Seting Penelitian}

Penelitian ini dilaksanakan di MAN Malang II kota Batu pada siswa kelas X A semester genap tahun pelajaran 2009/2010 yang berjumlah 28 siswa pada minggu ke-3 bulan April 2010. Pokok bahasan yang menjadi fokus pada penelitian ini adalah trigonometri dengan sub pokok bahasan fungsi trigonometri dan grafiknya dan persamaan trigonometri. 


\section{Data dan Sumber Data}

Data dalam penelitian ini ada dua jenis:

- Data kualitatif diperoleh dari hasil tes berpikir kreatif dengan media pohon matematika pada setiap akhir siklus, hasil observasi kegiatan guru dan siswa dalam pembelajaran, hasil catatan lapangan selama pembelajaran, dan hasil wawancara.

- Data kuantitatif diperoleh dari dokumen hasil belajar siswa sebelum dilakukan penelitian dan skor tes hasil belajar matematika siswa pada setiap akhir siklus.

\section{Prosedur Pengumpulan Data}

Untuk mengumpulkan data dalam penelitian ini, diperlukan teknik-teknik pengumpulan data sebagai berikut:

- Dokumentasi

- Tes, dalam penelitian ini tes digunakan untuk mengetahui kemampuan berpikir kreatif siswa dan mengetahui hasil belajar matematika siswa pada pokok bahasan trigonometri. Tes berpikir kreatif siswa dalam bentuk membuat pohon matematika dan tes hasil belajar matematika siswa berbentuk uraian sebanyak 5 butir soal yang dilaksanakan pada akhir siklus, setelah diberikan serangkaian tindakan.

- Observasi, dalam penelitian ini dilakukan untuk memperoleh data secara obyektif mengenai hal-hal yang terjadi selama pembelajaran berlangsung berupa aktivitas guru (peneliti) dan siswa.

- Catatan lapangan, catatan lapangan ini mencakup catatan khusus guru (peneliti) dan siswa selama proses pembelajaran berlangsung yang tidak terdapat dalam lembar observasi. Wawancara

- Wawancara, wawancara dalam penelitian ini dilakukan pada 3 siswa kelas X A, untuk mengetahui tanggapan tentang kegiatan pembelajaran setelah diberi tindakan.

\section{Instrumen Penelitian}

Instrumen-instrumen yang digunakan dalam penelitian ini adalah sebagai berikut:

- Soal tes yang digunakan dalam penelitian ini meliputi tes kemampuan berpikir kreatif siswa dengan media pohon matematika, dan soal tes hasil belajar matematika yang berupa soal uraian sebanyak 5 butir. Berikut adalah kisi-kisi soal tes pada siklus I.

Tabel 4. Kisi-kisi Soal Siklus I

\begin{tabular}{|c|c|c|c|c|c|c|c|}
\hline $\mathrm{NO}$ & $\begin{array}{l}\text { KOMPETENSI } \\
\text { DASAR }\end{array}$ & INDIKATOR & $\begin{array}{c}\text { SUB } \\
\text { MATERI }\end{array}$ & $\begin{array}{l}\text { JENIS } \\
\text { SOAL }\end{array}$ & $\begin{array}{c}\text { BENTUK } \\
\text { TES }\end{array}$ & BOBOT & $\begin{array}{c}\text { NO } \\
\text { SOAL }\end{array}$ \\
\hline \multirow[t]{5}{*}{1} & \multirow{5}{*}{$\begin{array}{l}\text { Merancang } \\
\text { model } \\
\text { matematika } \\
\text { dari masalah } \\
\text { yang berkaitan } \\
\text { dengan } \\
\text { perbandingan, } \\
\text { fungsi, } \\
\text { persamaan dan } \\
\text { identitas } \\
\text { trigonometri }\end{array}$} & \multirow[t]{5}{*}{$\begin{array}{l}\text { Menggambar } \\
\text { grafik fungsi } \\
\text { trigonometri } \\
\text { sederhana. }\end{array}$} & \multirow[t]{5}{*}{$\begin{array}{l}\text { Fungsi } \\
\text { trigonometr } \\
\text { i dan } \\
\text { grafiknya }\end{array}$} & $\begin{array}{c}\text { Soal } \\
\text { sedang }\end{array}$ & $\begin{array}{c}\text { Tes } \\
\text { Uraian }\end{array}$ & 19 & 1 \\
\hline & & & & $\begin{array}{c}\text { Soal } \\
\text { sedang }\end{array}$ & $\begin{array}{c}\text { Tes } \\
\text { Uraian }\end{array}$ & 19 & 2 \\
\hline & & & & $\begin{array}{c}\text { Soal } \\
\text { sedang }\end{array}$ & $\begin{array}{c}\text { Tes } \\
\text { Uraian }\end{array}$ & 20 & 3 \\
\hline & & & & $\begin{array}{r}\text { Soal } \\
\text { mudah }\end{array}$ & $\begin{array}{c}\text { Tes } \\
\text { Uraian }\end{array}$ & 18 & 4 \\
\hline & & & & $\begin{array}{c}\text { Soal } \\
\text { sukar }\end{array}$ & $\begin{array}{c}\text { Tes } \\
\text { Uraian }\end{array}$ & 24 & 5 \\
\hline
\end{tabular}

- Lembar observasi

- Lembar Catatan lapangan

- Pedoman wawancara 


\section{Teknik Analisis Data}

Data kualitatif dalam penelitian ini dianalisis menggunakan model analisis kualitatif dari Miles dan Huberman, sedangkan data kuantitatif dianalisis secara deskriptif dengan mencari persentase dan rata-rata kelas (Basrowi dan Suwandi, 2009:130).

\section{Analisis Data kualitatif}

Data-data kualitatif yang dianalisis dalam penelitian ini adalah hasil tes berpikir kreatif dengan media pohon matematika pada setiap akhir siklus, hasil observasi kegiatan guru dan siswa dalam pembelajaran, hasil catatan lapangan selama pembelajaran, dan hasil wawancara. Data-data ini dianalisis menggunakan model Miles dan Huberman dengan tahapan sebagai berikut (Sugiyono, 2008:246-253):

- Reduksi data.

- Penyajian data.

- Penarikan kesimpulan dan vertifikasi data.

Adapun data-data kualitatif yang dianalisis dalam penerapan pendekatan pembelajaran open ended dan problem posing dengan media pohon matematika ini adalah sebagai berikut:

- Tes Berpikir Kreatif dengan Media Pohon Matematika

Analisis data yang digunakan untuk menganalisis data hasil tes berpikir kreatif siswa yaitu dengan analisis deskriptif. Data-data yang diperoleh tersebut dihitung berdasarkan rumus persentase keberhasilan tindakan sebagai berikut:

$$
\text { Persentase Keberhasilan }=\frac{\sum \text { Skor yang dicapai }}{\sum \text { Skor maksimum }} \times 100 \%
$$

Taraf keberhasilan tindakan disesuaikan dengan persentase keberhasilan tindakan yang telah dihitung. Penentuan taraf keberhasilan tindakan seperti yang terlihat pada Tabel 3.2 berikut:

Tabel 5. Taraf Keberhasilan Tindakan Berpikir Kreatif

\begin{tabular}{|l|l|}
\hline Persentase Keberhasilan & Taraf Keberhasilan \\
\hline $75 \%<\mathrm{SR} \leq 100 \%$ & Sangat kreatif \\
\hline $50 \%<\mathrm{SR} \leq 75 \%$ & kreatif \\
\hline $25 \%<\mathrm{SR} \leq 50 \%$ & Cukup kreatif \\
\hline $10 \%<\mathrm{SR} \leq 25 \%$ & Kurang kreatif \\
\hline $0 \%<\mathrm{SR} \leq 10 \%$ & Tidak kreatif \\
\hline
\end{tabular}

(sumber: diadaptasi dari siswono, 2006:12-13)

Skor ketercapaian hasil tes berpikir kreatif mempunyai rentang antara 0\%-100\%. kemudian akan dihitung berapa $\%$ jumlah siswa yang tuntas dalam pembelajaran yaitu siswa yang mendapat skor $\geq 65 \%$. Cara menghitung persentase ketuntasan berpikir kreatif siswa adalah sebagai berikut:

$$
\Sigma \text { siswa yang mendapat skor } \geq 65 \%
$$

persentase ketuntasan $=$

$\Sigma$ siswa keseluruhan

\section{X $100 \%$}

Siswa dikatakan tuntas jika terdapat $\geq 75 \%$ siswa yang yang mendapat skor $\geq 65 \%$. Jika kriteria yang telah diuraikan di atas belum terpenuhi, maka tindakan dinyatakan belum berhasil dan perlu diadakan tindakan berikutnya yang lebih baik. Begitu juga sebaliknya jika kriteria tersebut telah dipenuhi maka tindakan dinyatakan berhasil dan suatu penelitian dapat dihentikan.

- Penerapan Pendekatan Pembelajaran Open Ended dan Problem Posing dengan Media Pohon Matematika

Analisis data yang digunakan untuk menganalisis data penerapan langkah-langkah pendekatan pembelajaran open ended dan problem posing dengan media pohon matematika yaitu dengan analisis deskriptif. Analisis yang dilakukan oleh peneliti baik dari aspek guru maupun siswa, yang kemudian dibandingkan tingkat keberhasilan tindakan dari setiap siklus. 
Data-data yang diperoleh tersebut dihitung berdasarkan rumus persentase keberhasilan tindakan sebagai berikut:

$$
\text { Persentase Keberhasilan }=\frac{\sum \text { Skor yang dicapai }}{\sum \text { Skor maksimum }} \times 100 \%
$$

Taraf keberhasilan tindakan disesuaikan dengan persentase keberhasilan tindakan yang telah dihitung. Penentuan taraf keberhasilan tindakan seperti yang terlihat pada Tabel 3.3 berikut:

Tabel 6. Taraf Keberhasilan Tindakan Penerapan Pembelajaran

\begin{tabular}{|l|l|}
\hline Persentase Keberhasilan & Taraf Keberhasilan \\
\hline $81-100 \%$ & Sangat baik \\
\hline $61-80 \%$ & Baik \\
\hline $41-60 \%$ & Cukup baik \\
\hline $21-40 \%$ & Kurang \\
\hline $0-20 \%$ & Sangat kurang \\
\hline
\end{tabular}

(Sumber: Riduwan dan Akdon, 2005:18)

Kriteria keberhasilan tindakan yang diajukan oleh peneliti yaitu seorang guru atau siswa dikatakan berhasil dalam menerapkan pendekatan pembelajaran open ended dan problem posing dengan media pohon matematika jika persentase keberhasilannya mencapai $81 \%$. Jika kriteria yang telah diuraikan di atas belum terpenuhi, maka tindakan dinyatakan belum berhasil dan perlu diadakan tindakan berikutnya yang lebih baik. Begitu juga sebaliknya jika kriteria tersebut telah dipenuhi maka tindakan dinyatakan berhasil dan suatu penelitian dapat dihentikan.

\section{Analisis Data Kuantitatif}

Data kuantitatif berupa skor tes hasil belajar akan dianalisis secara deskriptif, yaitu dengan mencari persentase ketuntasan belajar dan skor rata-rata tes akhir siklus siswa. Hal ini sejalan dengan pemikiran Basrowi dan Suwandi (2009:130) menyatakan bahwa data kuantitatif dapat dianalisis secara deskriptif (persentase, mean, median, dan lain-lain). Skor ketercapaian hasil belajar mempunyai rentang antara 0-100. kemudian akan dihitung berapa \% jumlah siswa yang tuntas dalam pembelajaran yaitu siswa yang mendapat skor $\geq 65$. Cara menghitung persentase ketuntasan belajar adalah sebagai berikut:

$$
\text { persentase ketuntasan belajar }=\underset{\Sigma \text { siswa keseluruhan }}{ } \times 100 \%
$$
berikut:

Menurut Sudjana (2008:109) menyatakan bahwa perumusan skor rata-rata adalah sebagai

$$
\begin{array}{ll}
\bar{X}=\frac{\sum X}{N} & \\
\text { Dengan: } & \overline{\mathrm{X}}=\text { rata-rata }(\text { mean }) \\
& \mathrm{X}=\text { jumlah seluruh skor } \\
& \mathrm{N}=\text { banyaknya Subjek }
\end{array}
$$

Siswa dikatakan tuntas belajar jika terdapat $\geq 75 \%$ siswa yang yang mendapat skor $\geq 65$ dan rata-rata kelas $\geq 65$ (skala 1-100). Jika kriteria yang telah diuraikan di atas belum terpenuhi, maka tindakan dinyatakan belum berhasil dan perlu diadakan tindakan berikutnya yang lebih baik. Begitu juga sebaliknya jika kriteria tersebut telah dipenuhi maka tindakan dinyatakan berhasil dan suatu penelitian dapat dihentikan. 


\section{Pengecekan Keabsahan Data}

Dalam penelitian ini, peneliti hanya menggunakan 3 teknik dari 7 teknik tersebut, yaitu:

- Ketekunan pengamatan, ketekunan pengamatan dilakukan dengan mendatangi lokasi penelitian terus-menerus selama periode pengumpulan data. Moleong (2006:329) mengatakan bahwa ketekunan pengamatan bermaksud menemukan ciri-ciri dan unsur-unsur dalam situasi yang sangat relevan dengan persoalan atau isu yang sedang dicari dan kemudian memusatkan diri pada hal-hal tersebut secara rinci..

- Triangulasi, triangulasi yang digunakan dalam penelitian ini adalah triangulasi metode. Teknik triangulasi metode menurut Patton (dalam Moleong, 2006:331) terdapat dua strategi, yaitu; (1) pengecekan derajat kepercayaan penemuan hasil penelitian beberapa teknik pengumpulan data dan (2) pengecekan derajat kepercayaan beberapa sumber data dengan metode yang sama, tetapi dalam penelitian ini teknik triangulasi metode yang digunakan adalah pengecekan derajat kepercayaan dengan metode tes, observasi, wawancara, dan catatan lapangan.

- Pemeriksaan sejawat, diskusi dengan guru mata pelajaran dan teman sejawat dimaksudkan untuk membicarakan proses dan hasil penelitian. Dari hasil diskusi secara informal peneliti memperoleh masukan-masukan baik dari segi metodologi maupun konteks penelitian, sehingga untuk memberi tindakan yang berikutnya peneliti bisa lebih memperbaikinya.

\section{PEMBAHASAN}

\section{Hasil Analisis Data Kualitatif}

- Tes Berpikir Kreatif Siswa dalam Membuat Pohon Matematika

Tabel 7. Hasil Tes Berpikir Kreatif Siswa dalam Membuat Pohon Matematika

\begin{tabular}{|c|c|c|}
\hline Siklus & Persentase Keberhasilan & Taraf Keberhasilan \\
\hline I & $67,85 \%$ & Kreatif \\
\hline II & $78,57 \%$ & Sangat Kreatif \\
\hline
\end{tabular}

Tabel 8. Kemampuan Berpikir Kreatif Siswa Siklus I dan II

\begin{tabular}{|c|c|c|}
\hline Indikator & Siklus I & Siklus II \\
\hline Kelancaran (fluently) & $89,88 \%$ & $88,69 \%$ \\
\hline Keaslian (Originality) & $40,48 \%$ & $66,67 \%$ \\
\hline Penguraian (Elaboration) & $38,10 \%$ & $48,80 \%$ \\
\hline
\end{tabular}

Dari Tabel 7 dan 8 dapat diketahui bahwa hasil tes berpikir kreatif siswa dalam membuat pohon matematika pada siklus I mencapai $67,85 \%$ dengan taraf keberhasilan kreatif sedangkan pada siklus II mengalami peningkatan mencapai 78,57\% dengan taraf keberhasilan sangat kreatif. Persentase ini sudah memenuhi taraf keberhasilan yang ditetapkan peneliti, yaitu $75 \%$ siswa mencapai skor tes $\geq 65 \%$, sedangkan dari Tabel 4.12 dapat dilihat untuk indikator kelancaran (fluently) menurun dari $89,88 \%$ menjadi $88,69 \%$, indikator keaslian (fluently) meningkat dari $40,48 \%$ menjadi $66,67 \%$, dan indikator penguraian (elaboration) meningkat dari $38,10 \%$ menjadi $48,80 \%$. Dari siklus I dan siklus II , dapat disimpulkan bahwa kemampuan berpikir kreatif siswa telah mengalami peningkatan dan telah mencapai kriteria keberhasilan yang ditetapkan peneliti.

- Kegiatan guru pada pelaksanaan siklus I dan II

Tabel 9. Hasil Analisis Kegiatan Guru dengan Pendekatan Pembelajaran Open Ended dan Problem Posing dengan Media Pohon Matematika Siklus I dan Siklus II

\begin{tabular}{|c|c|c|c|}
\hline Siklus & Pertemuan & $\begin{array}{c}\text { Persentase } \\
\text { Keberhasilan } \\
\text { Tindakan }\end{array}$ & Taraf Keberhasilan \\
\hline I & Pertama & $73 \%$ & Baik \\
\hline & Kedua & $88 \%$ & Sangat Baik \\
\hline II & Pertama & $100 \%$ & Sangat Baik \\
\hline & Kedua & $100 \%$ & Sangat Baik \\
\hline
\end{tabular}


Dari hasil analisis tersebut dapat dilihat bahwa kegiatan guru pada siklus I pada pertemuan pertama mencapai $88 \%$ dengan taraf keberhasilan baik dan pada pertemuan kedua mengalami peningkatan mencapai $88 \%$ dengan taraf keberhasilan sangat baik. Persentase ini sudah memenuhi taraf keberhasilan yang ditetapkan oleh peneliti, yaitu $81 \%$. Sedangkan pada pertemuan pertama dan kedua siklus II persentase ini meningkat menjadi 100\% dengan taraf keberhasilan sangat baik. Persentase ini sudah mencapai taraf keberhasilan yang ditetapkan oleh peneliti, yitu $81 \%$. Sehingga dapat disimpulkan bahwa pembelajaran dari segi guru telah berhasil, baik pada siklus I maupun siklus II.

- Kegiatan Siswa pada Pelaksanaan Siklus I dan Siklus II

\section{Tabel 10. Hasil Analisis Kegiatan Guru dengan Pendekatan Pembelajaran Open Ended dan Problem Posing dengan Media Pohon Matematika Siklus I dan Siklus II}

\begin{tabular}{|c|c|c|l|}
\hline Siklus & Pertemuan & $\begin{array}{c}\text { Persentase } \\
\text { Keberhasilan } \\
\text { Tindakan }\end{array}$ & Taraf Keberhasilan \\
\hline I & Pertama & $72 \%$ & Baik \\
\hline & Kedua & $82,5 \%$ & Sangat Baik \\
\hline II & Pertama & $99,28 \%$ & Sangat Baik \\
\hline & Kedua & $100 \%$ & Sangat Baik \\
\hline
\end{tabular}

Dari Tabel 10 dapat diketahui bahwa kegiatan siswa pada siklus I pertemuan pertama mencapai $72 \%$ dengan taraf keberhasilan baik sedangkan pada pertemuan kedua mengalami peningkatan mencapai $82,5 \%$ dengan taraf keberhasilan sangat baik. Persentase ini sudah memenuhi taraf keberhasilan yang ditetapkan peneliti, yaitu $81 \%$, namun peneliti tetap melanjutkan pada siklus berikutnya untuk melihat keajegan kegiatan belajar siswa dalam pembelajaran. Pada siklus II persentase keberhasilan meningkat mencapai $100 \%$ dengan taraf keberhasilan sangat baik. Dari siklus I dan siklus II, kegiatan siswa telah mencapai kriteria yang ditetapkan peneliti, yaitu $81 \%$. Sehingga dapat disimpulkan bahwa pembelajaran dari segi siswa telah berhasil, baik pada siklus I maupun siklus II.

\section{Hasil Analisis Data Kuantitatif}

Tabel 11. Hasil Tes Belajar Siklus I dan Siklus II

\begin{tabular}{|c|c|c|c|l|}
\hline Siklus & Jumlah Siswa & $\begin{array}{c}\text { Jumlah Siswa } \\
\text { Tuntas }\end{array}$ & $\begin{array}{c}\text { Persentase } \\
\text { Ketuntasan }\end{array}$ & Keterangan \\
\hline I & 28 & 14 & $50,00 \%$ & Tidak Tuntas \\
\hline II & 28 & 25 & $89,28 \%$ & Tuntas \\
\hline
\end{tabular}

Dari Tabel 11 di atas dapat diketahui bahwa hasil tes akhir pada siklus I mencapai 50,00\% dari 28 siswa yang mengikuti tes dan siswa yang tuntas 14 siswa dengan keterangan tidak tuntas dalam siklus I. persentase ini belum memenuhi taraf keberhasilan yang ditetapkan, yaitu $75 \%$ siswa mendapat nilai $\geq 65$ sehingga peneliti merencanakan siklus berikutnya. Sedangkan pada siklus II persentase ini meningkat menjadi $89,28 \%$ dari 28 siswa yang mengikuti tes dan siswa yang tuntas 25 siswa dengan keterangan tuntas dalam siklus II. Persentase ini sudah mencapai taraf keberhasilan yang telah ditetapkan, yaitu75\% siswa mendapat nilai $\geq 65$ sehingga siklus dapat dihentikan.

Dari hasil analisis data kualitatif dan kuantitatif di atas dapat diketahui bahwa pembelajaran baik dari segi guru maupun siswa telah mengalami peningkatan dan sesuai dengan standart keberhasilan yang telah ditetapkan.

\section{Pembahasan Penelitian}

Beberapa hasil penelitian yang telah dilakukan menggunakan pendekatan pembelajaran open ended dan problem posing dengan media pohon matematika, diantaranya adalah penelitian yang dilakukan oleh Fidia Lestariningsih Jurusan Matematika FMIPA UM terhadap siswa kelas II MTs 
Surya Buana Malang pokok bahasan "persamaan kuadrat" pada tahun 2007, tentang pendekatan pembelajaran open ended dan problem posing dengan media pohon matematika. Hasil penelitiannya menunjukkan bahwa kegiatan pembelajaran tersebut mampu meningkatkan prestasi belajar dan kreativitas siswa.

Berdasarkan data pengamatan setelah diberi tindakan pada siklus I dan siklus II guru dapat mengungkapkan perubahan yang terjadi pada siswa. Perubahan tersebut adalah sebagai berikut (1) penerapan pendekatan pembelajaran open ended dan problem posing dengan media pohon matematika dapat meningkatkan antusias siswa dalam belajar matematika karena siswa merasa senang sehingga berdampak pada prestasi belajarnya, hal ini sesuai dengan pendapat yang dikemukakan oleh English, Silver, dan Cai (dalam Subanji, 2007:3) bahwa pengajuan masalah dapat membantu siswa dalam mengembangkan keyakinan dan kesukaan terhadap matematika, sebab ide-ide matematika siswa dicobakan untuk memahami masalah yang sedang dikerjakan dan dapt meningkatkan perfomannya dalam pemecahan masalah; (2) penerapan pendekatan pembelajaran open ended dan problem posing dengan media pohon matematika dapat meningkatkan kemampuan berpikir kreatif siswa. Hal ini sesuai dengan pendapat yang dikemukakan oleh Siswono (2000:7) pengajuan soal merupakan tugas kegiatan yang mengarah pada sikap kritis dan kreatif karena melibatkan siswa aktif dalam pengorganisasian dan penemuan informasi saat pembelajaran berlangsung sehingga akan menghasilkan peningkatan pengetahuan dan meningkatkan ketrampilan berpikir; dan (3) penerapan pendekatan pembelajaran open ended dan problem posing dengan media pohon matematika dapat meningkatkan hasil belajar siswa. Hal ini sesuai dengan pendapat yang dikemukakan oleh Subanji (2007:2) bahwa pendekatan pembelajaran open ended dan problem posing dapat meningkatkan prestasi belajar siswa.

Berikut perolehan data dari penerapan pendekatan pembelajaran open ended dan problem posing dengan media pohon matematika untuk meningkatkan kemampuan berpikir kreatif dan hasil belajar trigonometri siswa kelas X A MAN Malang II Kota Batu tahun pelajaran 2009/2010 dapat dilihat pada Tabel 12.

Tabel 12. Data Hasil Penelitian

\begin{tabular}{|l|l|l|l|l|}
\hline \multicolumn{1}{|c|}{ Keterangan } & \multicolumn{1}{|c|}{ Siklus I } & \multicolumn{1}{|c|}{$\begin{array}{c}\text { Taraf } \\
\text { Keberhasilan }\end{array}$} & \multicolumn{1}{|c|}{ Siklus II } & $\begin{array}{c}\text { Taraf } \\
\text { Keberhasilan }\end{array}$ \\
\hline $\begin{array}{l}\text { Kemampuan } \\
\text { berpikir kreatif }\end{array}$ & $67,85 \%$ & Kreatif & $78,57 \%$ & Sangat Kreatif \\
\hline $\begin{array}{l}\text { Observasi terhadap } \\
\text { guru }\end{array}$ & $88 \%$ & Sangat Baik & $100 \%$ & Sangat Baik \\
\hline $\begin{array}{l}\text { Observasi terhadap } \\
\text { siswa }\end{array}$ & $82,5 \%$ & Sangat Baik & $100 \%$ & Sangat Baik \\
\hline $\begin{array}{l}\text { Persentase } \\
\text { ketuntasan }\end{array}$ & $50,00 \%$ & Tidak tuntas & $89,28 \%$ & Tuntas \\
\hline Rata-rata kelas & 63,25 & Tidak tuntas & 80,46 & Tuntas \\
\hline
\end{tabular}

- Penerapan pendekatan pembelajaran open ended dan problem posing dengan media pohon matematika

Penerapan pendekatan pembelajaran open ended dan problem posing dengan media pohon matematika terdapat tiga tahap yaitu (1) tahap penyajian materi, yakni membuka proses belajar mengajar dengan salam dan mempresensi, memotivasi siswa dengan mengingatkan pembelajaran sebelumnya, menyampaikan tujuan pembelajaran, mengarahkan guru untuk tidak mendominasi kelas, mengarahkan siswa untuk aktif di dalam proses pembelajaran, menyajikan materi, memberikan stimulus kepada siswa tentang materi yang diajarkan berupa pertanyaan, dan meminta siswa untuk membuat soal sebanyak-banyaknya; (2) tahap merancang pohon matematika, dalam tahap guru menjelaskan aturan dalam belajar dengan media pohon matematika, memberi kesempatan kepada siswa untuk bertanya jika belum jelas, menyediakan sarana dan prasarana untuk kegiatan pembelajaran, membantu/mendampingi siswa dalam bekerja, Mengarahkan siswa untuk menyelesaikan soal dalam menumbuhkan daun pada media pohon matematika, dan mengarahkan siswa untuk membuat soal yang memiliki selesaian yang tidak tunggal; (3) tahap Evaluasi, menunjuk 
siswa untuk mempresentasikan hasil pekerjaanya di depan, membuat kesimpulan bersama dengan siswa, memberikan tugas dan gambaran materi pada pertemuan berikutnya, dan mengakhiri pembelajaran dengan salam.

- Kemampuan Berpikir Kreatif

Berdasarkan deskripsi penelitian mengenai hasil kemampuan berpikir kreatif

yang diukur melalui tes membuat pohon matematika, dapat diketahui bahwa kemampuan berpikir kreatif siswa kelas X A MAN Malang II Kota Batu tahun ajaran 2009/2010 tergolong "sangat kreatif" yaitu dengan persentase keberhasilan 78,57\%, dengan indikator kelancaran (fluently) mencapai $88,69 \%$, indikator keaslian (Originality) mencapai $66,67 \%$, dan indikator penguraian (Elaboration) mencapai 48,80\%.

- Hasil Belajar Siswa

Dari hasil data yang diperoleh dalam penelitian ini, dapat dikatakan bahwa ketuntasan belajar siswa sudah tercapai, karena terdapat $89,28 \%$ siswa dalam kelas yang mendapat skor $\geq 65$, skor ini merupakan skor SKBM (Standar Ketuntasan Belajar Minimal) yang telah ditentukan oleh pihak sekolah. Dalam penelitian ini siswa yang telah mencapai SKBM sebanyak $89,28 \%$, persentase ini sudah melebihi standar ketuntasan belajar siswa keseluruhan yaitu $75 \%$. Sedangkan rata-rata kelas mencapai skor 80,46 , skor ini sudah melebihi standar ketuntasan belajar minimal yaitu rata-rata kelas $\geq 65$.

- Pengelolaan Pembelajaran menggunakan pendekatan pembelajaran open ended dan problem posing dengan media pohon matematika

Berdasarkan hasil pengamatan yang telah dilakukan dalam penelitian ini, maka pengelolaan pendekatan pembelajaran open ended dan problem posing dengan media pohon matematika sudah mencapai $100 \%$. Dari data ini dapat diketahui bahwa guru dalam penelitian ini telah melaksanakan proses pembelajaran dengan sangat baik.

- Kegiatan siswa dalam pembelajaran menggunakan pendekatan pembelajaran open ended dan problem posing dengan media pohon matematika

Dari hasil keseluruhan pengamatan yang dilakukan, kegiatan siswa dalam pembelajaran menggunakan pendekatan pembelajaran open ended dan problem posing dengan media pohon matematika sudah mencapai $100 \%$. Dari data ini dapat diketahui bahwa siswa terlihat sangat baik dalam mengikuti pembelajaran menggunakan pendekatan pembelajaran open ended dan problem posing dengan media pohon matematika yakni siswa sudah berani bertanya tentang hal-hal yang belum dipahami, siswa berani mengutarakan pendapatnya dalam membuat soal dan menjawabnya melalui media pohon matematika, siswa berani mempresentasikan hasil pengerjaannya di depan kelas.

Dari uraian di atas, dapat disimpulkan bahwa pendekatan pembelajaran open ended dan problem posing dengan media pohon matematika merupakan salah satu bentuk inovasi dalam memperbaiki kualitas proses pembelajaran matematika yang bertujuan untuk membantu siswa dalam meningkatkan kemampuan berpikir kreatif dan hasil belajar trigonometri. Jadi dalam penelitian ini, penerapan pendekatan pembelajaran open ended dan problem posing dengan media pohon matematika dapat meningkatkan kemampuan berpikir kreatif dan hasil belajar trigonometri siswa kelas X A MAN Malang II Kota Batu tahun pelajaran 2009/2010.

\section{PENUTUP}

\section{Simpulan}

Berdasarkan paparan data dan pembahasan hasil penelitian yang telah dipaparkan pada bab IV, maka penelitian ini dapat disimpulkan bahwa penerapan pendekatan pembelajaran open ended dan problem posing dengan media pohon matematika dapat meningkatkan kemampuan berpikir kreatif dan hasil belajar trigonometri siswa kelas X A MAN Malang II Kota Batu tahun pelajaran 2009/2010. Pada siklus I diperoleh persentase keberhasilan kemampuan berpikir kreatif mencapai 67,85\% dengan kriteria keberhasilan kreatif, hasil tes belajar diperoleh rata-rata 63,25 dan sekitar 50,00\% siswa yang tuntas pada pokok bahasan trigonometri dengan sub pokok bahasan fungsi trigonometri dan grafiknya. Pada siklus II diperoleh persentase keberhasilan kemampuan berpikir kreatif mencapai 78,57\% dengan kriteria keberhasilan sangat kreatif, hasil tes belajar diperoleh rata-rata 80,46 dan sekitar $89,28 \%$ siswa yang tuntas pada pokok bahasan trigonometri dengan sub pokok bahasan persamaan trigonometri 


\section{Saran}

Untuk penelitian berikutnya disarankan untuk menggunakan pendekatan pembelajaran open ended dan problem posing dengan media pohon matematika dalam bentuk kelompok. Media pohon matematika bisa dibuat melalui media flash atau yang lainnya.

\section{DAFTAR RUJUKAN}

Aqib, Zainal. 2006. Penelitian Tindakan Kelas untuk Guru. Bandung: Yrama Widya.

Arikunto, Suharsimi., Suhardjono., dan Supardi. 2008. Penelitian Tindakan Kelas. Jakarta: Bumi Aksara.

Arikunto, Suharsimi. 2006. Prosedur Penelitian Suatu Pendekatan Praktik. Jakarta: Rineka Cipta.

Asnawir dan Usman.2002. Media Pembelajaran. Jakarta: Ciputat Pers

Basrowi dan Suwandi. 2008. Penelitian Tindakan Kelas. Bogor: Ghalia Indonesia.

Cahyono.2008.Pendekatan Pembelajaran. (online),http://www.pdf-search-engine.com/pendekatanpembelajaran-pdf.html, diakses pada 27 januari 2009).

Dimiyati dan Mudjiono. 2006. Belajar dan Pembelajaran. Jakarta: Rineka Cipta.

Hudojo, Herman. 2005. Kapita Selekata Pembelajaran Matematika. Malang: Universitas Negeri Malang (UM Press).

Jihad dan Haris. 2009. Evaluasi Pembelajaran. Yogyakarta: Multi Pressindo

Johnson, Elaine B. 2007. Contextual Teaching \& Learning. Jakarta: Bumi Aksara

Mariana. Neni. 2005. Kreativitas Siswa dalam Mengajukan Masalah (Problem Posing) Matematika. Makalah Disajikan pada Seminar Nasional Matematika dan Pendidikan Matematika di Universitas Negeri Surabaya pada Tanggal 28 Februari 2005.

Moleong, Lexy. 2006. Metodologi Penelitian Kualitatif. Bandung: Remaja Rosdakarya.

Mustangin. 2002. Dasar-dasar Pembelajaran Matematika. Modul tidak diterbitkan. Malang: Unversitas Islam Malang.

Riduwan dan Akdon. 2005. Rumus dan Data dalam Aplikasi Statistika. Bandung: Alfabeta.

Sagala, Syaiful. 2005. Konsep dan Makna Pembelajaran. Bandung: Alfabeta.

Siswono dan Rosyidi. 2005. Menilai Kreativitas Siswa dalam Matematika. Makalah Disajikan pada Seminar Nasional Matematika dan Pendidikan Matematika di Universitas Negeri Surabaya pada Tanggal 28 Februari 2005.

Slameto. 2003. Belajar dan Faktor-Faktor yang Mempengaruhinya. Jakarta: Rineka cipta.

Soedjadi. 2000. Kiat Pendidikan Matematika di Indonesia. Jakarta: Departemen Pendidikan Nasional.

Subanji.2007. Pembelajaran dengan Pohon Matematika Sebagai Upaya Meningkatkan Kreativitas Siswa.(online),

http://www.4shared.com/file/92858906/de9f333f/makalah_pohon_mat_Subanji_UM.html, diakses pada 3 desember 2009).

Sudjana, Nana. 2008. Penilaian Hasil Proses Belajar Mengajar. Bandung: Remana Rosdakarya.

Sudrajat, Akhmad. 2008. Pengertian Pendekatan, Strategi, Metode, Teknik, Taktik dan Model Pembelajaran, (online), (http://www.psb-psma.org/content/blog/pengertian-pendekatanstrategi-metode-teknik-taktik-dan-model-pembelajaran, diakses pada tanggal 21 September 2009).

Suherman, Erman, dkk. 2003. Strategi Pembelajaran Matematika Kontemporer. Bandung: Jica.

Sugiyono. 2008. Metode Penelitian Kuantitatif Kualitatif dan R\&D. Bandung: Alfabeta.

Sumardyono.2004.Karakteristik Matematika dan Implikasinya terhadap Pembelajaran Matematika.(online),( http://www.pdf-search-engine.com/karakteristik-matematika-pdf.html, diakses pada 27 januari 2009).

Suryosubroto, B. 2009. Proses Belajar Mengajar di Sekolah. Jakata: Rineka Cipta.

Syafruddin.2009.Pendekatan Open Ended dan Problem posing Dalam Matematika. Makalah (online),(http://mathematicse.wordpress.com/2007/12/25/open-ended-problems-dalammatematika, diakses pada 28 Mei 2009).

Warli. 2005. Meningkatkan Kemampuan Berpikir Kreatif Siswa melalui Pembelajaran Berbasis Masalah. Makalah Disajikan pada Seminar Nasional Matematika dan Pendidikan Matematika di Universitas Negeri Surabaya pada Tanggal 28 Februari 2005.

Wiriaatmadja, Rochiati. 2007. Metode Penelitian Tindakan. Bandung: Remaja Rosdakarya.

Yuwono dan Indriyastuti. 2008. Perspektif Metematika 1. Solo: PT Tiga Serangkai Pustaka Mandiri. 